\title{
Phosphorylation of Prion Protein at Serine 43 Induces Prion Protein Conformational Change
}

\author{
Paresa N. Giannopoulos, ${ }^{1}$ Catherine Robertson, ${ }^{2,3}$ Julie Jodoin, ${ }^{1,4}$ Hemant Paudel, ${ }^{1,4}$ Stephanie A. Booth, ${ }^{2,3}$ and \\ Andrea C. LeBlanc ${ }^{1,4}$ \\ ${ }^{1}$ The Bloomfield Centre for Research in Aging, Lady Davis Institute for Medical Research, The Sir Mortimer B. Davis Jewish General Hospital, Montréal, \\ Québec H3T 1E2, Canada, ${ }^{2}$ Molecular Pathobiology, National Microbiology Laboratory, Winnipeg, Manitoba R3E 3R2, Canada, ${ }^{3}$ Department of Medical \\ Microbiology, University of Manitoba, Winnipeg, Manitoba R3E 0J9, Canada, and ${ }^{4}$ Department of Neurology and Neurosurgery, McGill University, \\ Montréal, Québec H3A 2T5, Canada
}

The cause of the conformational change of normal cellular prion protein (PrP) into its disease-associated form is unknown. Posttranslational modifications, such as glycosylation, acetylation, $S$-nitrosylation, and phosphorylation, are known to induce protein conformational changes. Here, we investigated whether phosphorylation could induce the conformational change of PrP because PrP contains several kinase motifs and has been found recently in the cytosol, in which kinases generally reside. Neuronal cyclin-dependent kinase 5 (Cdk5) phosphorylated recombinant $\operatorname{PrP}_{23-231}$ at serine 43 (S43) in an in vitro kinase assay. Cdk5-phosphorylated PrP became proteinase K resistant, formed Congo Red-positive fibrils, and formed aggregates that were immunostained with anti-PrP and anti-phospho-PrP ${ }^{\mathrm{S} 43}$ (anti-pPrP ${ }^{\mathrm{S43}}$ ). $\mathrm{pPrP}^{\mathrm{S} 43}$ was detected in PrP/Cdk5/p25 cotransfected N2a cells. Roscovitine inhibition of Cdk5 activity or transfection of $\mathrm{N} 2 \mathrm{a}$ cells with mutant $\mathrm{PrP}$ S43A eliminated the anti-pPrP ${ }^{\mathrm{S} 3}$-immunopositive protein. Alkaline phosphatase-sensitive and proteinase $\mathrm{K}$-resistant $\mathrm{pPrP}^{\mathrm{S4}}$ immunoreactivity was observed in scrapie-infected but not control-injected mice brains. These results raise the possibility that phosphorylation could represent a physiological mechanism of PrP conversion in vivo.

\section{Introduction}

Although it is widely accepted that conversion of normal cellular prion protein $(\mathrm{PrP})$ into a proteinase $\mathrm{K}(\mathrm{PK})$ resistant $\left(\mathrm{PK}^{\mathrm{RES}}\right.$ or $\mathrm{PrP}^{\mathrm{RES}}$ ) aberrant conformational form is associated with transmissible spongiform encephalopathies, the underlying molecular mechanism of this conversion is not clear. The hypothesis that prion protein in the form of $\operatorname{PrP}^{\mathrm{RES}}$ or $\operatorname{PrP}$ scrapie $\left(\mathrm{PrP}^{\mathrm{Sc}}\right)$ is responsible for conversion of normal cellular $\mathrm{PrP}$ is well supported in vivo and in vitro. $\mathrm{PrP}^{\mathrm{Sc}}$ seeded conversion is observed by infecting live animals (Prusiner, 1982; Caughey, 1993), specific cell lines (Race et al., 1987), and cell-free mammalian protein systems (Neary et al., 1991; Kocisko et al., 1994; Bessen et al., 1995; Saborio et al., 2001; Deleault et al., 2007).

Conversion is also observed in the absence of $\operatorname{PrP}^{\mathrm{Sc}}$ seed in vivo. Single point and insertional octapeptide repeat mutations of the Prnp gene generate $\operatorname{PrP}^{\text {RES }}$ (Monari et al., 1994; Tateishi and Kitamoto, 1995; Mastrianni et al., 2001; Piccardo et al., 2001; Grasbon-Frodl et al., 2004). Transgenic mice expressing the

\footnotetext{
Received May 15, 2009; accepted June 3, 2009.

This work was supported by the National Institutes of Health Grant 1R01 NS40431, Canadian Institutes for Health Research Grant MOP-49594, and Fonds de Recherche en Santé du Québec (A.C.L.) and the Public Health Agency of Canada, the Canadian Biotechnology Strategy Fund: Genomics Initiative for Government Laboratories and Public Health Service and Prionet Canada (S.A.B.). We thank Dr. Witold Surewicz (Case Western Reserve University, Cleveland, $\mathrm{OH}$ ) for providing recombinant PrP and Dr. Hajatollah Vali (Department of Anatomy and Cell Biology, McGill University, Montréal, Québec, Canada) for helping with the electron microscopy work.

Correspondence should be addressed to Dr. Andréa LeBlanc, The Bloomfield Centre for Research in Aging, Lady Davis Institute for Medical Research, The Sir Mortimer B. Davis Jewish General Hospital, 3755 Chemin Côte SteCatherine, Montréal, QC H3T 1E2, Canada. E-mail: andrea.leblanc@mcgill.ca.

D01:10.1523/JNEUROSCI.2294-09.2009

Copyright $\odot 2009$ Society for Neuroscience $\quad$ 0270-6474/09/298743-09\$15.00/0
}

Gertsmann-Sträussler-Scheinker-associated PrP P101L mutation or PrP with a nine octapeptide repeat insertion result in a mild $\mathrm{PrP}^{\mathrm{RES}}$ form of $\mathrm{PrP}$ (Hsiao et al., 1990; Chiesa et al., 1998). In the absence of a PrP mutation, endoplasmic reticulum associated degradation pathway-generated cytosolic PrP becomes $\mathrm{PK}^{\mathrm{RES}}$ in mouse neuroblastoma Neuro2a (N2a) cells; however, this does not occur in human primary neurons or human neuroblastoma cell lines (Ma and Lindquist, 2002; Ma et al., 2002; Roucou et al., 2003).

In vitro, purified human, hamster, or mouse $\operatorname{PrP}_{90-231}$ or $\mathrm{PrP}_{23-231}$ convert under acidic $\mathrm{pH}$, mild denaturant conditions, treatment with $0.1 \%$ SDS and sonication, and protein misfolded cyclic amplification (PMCA) assay in the presence of RNA (Swietnicki et al., 1997; Jackson et al., 1999; Swietnicki et al., 2000; Deleault et al., 2003; Bocharova et al., 2006; Lührs et al., 2006; Atarashi et al., 2007; Wang et al., 2007). Methionine oxidation, high-pressure, $\mathrm{Al}^{3+}$ and $\mathrm{Zn}^{2+}$ also promote conversion of $\mathrm{PrP}$ and PrP fragments (Torrent et al., 2004; Breydo et al., 2005; Ricchelli et al., 2006). Conversion of PrP appears to first involve the formation of oligomers that evolve into fibrillar structures with time and give $\mathrm{PK}^{\mathrm{RES}}$ fragments between 8 and $16 \mathrm{kDa}$ (Jackson et al., 1999; Swietnicki et al., 2000; Xiong et al., 2001; Sokolowski et al., 2003; Breydo et al., 2005; Lührs et al., 2006). Transmissibility of disease from $\mathrm{PrP}^{\mathrm{Sc}}$-free conversions has been observed only in two situations: by the injection of Escherichia coli-purified fibrillar $\mathrm{PrP}_{89-231}$ in brains of transgenic mice overexpressing $\operatorname{PrP}_{89-}$ 231 (Legname et al., 2004) and by infecting wild-type hamsters with purified mammalian PrP submitted to PMCA in the presence of poly-anions (Deleault et al., 2007). 
Table 1. Conservation of phosphorylation motifs in PrP amongst various species

\begin{tabular}{|c|c|c|c|c|c|}
\hline Putative motif & Phospho AA & Mammals & Chicken & Turtle & Doppel \\
\hline PGQSPGGN & S43 & All & $\mathrm{RQ}$ & SN & \\
\hline IHFGSDYED & S143 & Only in human, bovine, and bison & $S$ & $\mathrm{R}$ & A \\
\hline FGSDYEDRY & Y145 & W in rat, mouse, and hamster & D & $E$ & \\
\hline YEDRYYREN & Y149 & All & WW & WW & YY \\
\hline PMDEYSNQN & Y169 & All & & $\mathrm{R}$ & A \\
\hline HTVTTTTKG & T191 & All & $P$ & $P$ & $\mathrm{~F}$ \\
\hline TVTTTTKGE & T192 & All & A & $\mathrm{N}$ & Q \\
\hline VTTTTKGEN & T193 & All & A & $\mathrm{E}$ & K \\
\hline YQRGSSMVL & S230 & All except rabbit & $S$ & $S$ & A \\
\hline QRGSSMVLF & S231 & All except rabbit & G & G & G \\
\hline VLFSSPPVI* & S237 & All & $A D$ & $\mathrm{DP}$ & $\mathrm{HQ}$ \\
\hline
\end{tabular}

Mammalian species examined are human, guar, macaque, kudu, bison, rhesus monkey, baboon, mink, rabbit, camel, rat, nilgai, sheep, mouse, hamster, cattle, and cat. Human Doppel was also included. The phosphorylation sites were identified with NetPhos 2.0 Server in EXPASY and had significant scores, except the last SP motif $\left({ }^{*}\right)$, which has low predictability for phosphorylation.

Several anionic conditions, such as anionic detergents, synthetic poly-anions, RNA, and low $\mathrm{pH}$ conditions, favor the conformational change of PrP in vitro (Deleault et al., 2003, 2005, 2007; Supattapone, 2004; Geoghegan et al., 2007). Therefore, here, we considered the hypothesis that phosphorylation of PrP, which would also provide anionic conditions, could affect PrP conformation.

\section{Materials and Methods}

Antibodies. The following commercially available antibodies were used: monoclonal 3F4 anti-PrP ${ }^{109-112}$ (Kascsak et al., 1987), monoclonal 6H4 anti-PrP ${ }^{144-156}$ (Prionics), monoclonal phospho-Tyr (pTyr-100) (Cell Signaling Technology), HRP-conjugated goat anti-rabbit or anti-mouse IgG (GE Healthcare), and $\beta$-actin (Sigma-Aldrich). The polyclonal R155 anti-PrP ${ }^{36-56}$ was produced in our laboratory. The human PrP peptide Gly-phospho-Ser-Pro-Gly-Gly-Asn-Arg-Tyr-Pro terminating with an added Cys was synthesized, purified, conjugated to keyhole limpet hemocyanin, and injected into rabbits by Sigma-Genosys. ELISA performed by Sigma-Genosys gave a titer of 1:25,000 for non-phosphopeptide and 1:500,000 for phospho-peptide after the first production bleed. The antiserum anti-phospho-Prp ${ }^{\mathrm{S43}}\left(\mathrm{pPrP}^{\mathrm{S43}}\right)$ was used at a titer of 1:100 for Western blots and 1:250 for immunoprecipitation.

Site-directed mutagenesis of $\operatorname{PrP}$ and $\operatorname{PrP}$ purification. PrP S43A was generated by QuikChange site-directed mutagenesis (Jodoin et al., 2007) with the forward primer 5'-CCGGGGCAGGGCGCACCTGGAGGCAACC- $3^{\prime}$ and the reverse primer $5^{\prime}$-GGTTGCCTCCAGGTGCGCCCTGCCCCGG-3', from pBKSII-PrP ${ }_{23-231}$ cDNA. The S43A mutation was confirmed by BglI digestion. PrP and PrP S43A were subcloned into the $B a m H I$ and XhoI sites of the pET-23b $(+)$ vector (EMD Chemicals) after PCR amplification with the forward primer 5'-ACGCGGATCCCAAGAAGCGCCCGAAGCCT-3' and the reverse primer 5'-GCCGCTCGAGGCTCGATCCTCTCTGGTA- ${ }^{\prime}$. The expression of C-terminally His-tagged $\operatorname{PrP}$ was induced in $\mathrm{pET}-23 \mathrm{~b}(+) \operatorname{PrP}$ or $\operatorname{PrP}$ S43Atransformed E. coli BL21(DE3)pLysS (Stratagene) with isopropyl- $\beta$-Dthiogalactopyranoside and purified as described previously (Gilch et al., 2003). In addition, PrP S43A was introduced into pCep $4 \beta-\operatorname{PrP}$ full length (Bounhar et al., 2001) by QuikChange site-directed mutagenesis.

Kinase assay. One microliter of cyclin-dependent kinase 5 (Cdk5) kinase extracted from bovine brain (Paudel et al., 1993), $1.5 \mathrm{U}$ of recombinant glutathione $S$-transferase (GST)-Cdk5 with 2 U of GST-p25 (Calbiochem), or $500 \mathrm{U}$ of Casein kinase II (CKII) (Biomol Research Laboratories) were added to $0.45 \mu \mathrm{g} / \mu \mathrm{l} \operatorname{PrP}$ (a generous gift from Dr. Witold Surewicz, Case Western Reserve University, Cleveland, $\mathrm{OH}$ ) in kinase assay buffer containing 110.5 mM HEPES, pH 7.2, 0.15 mM EDTA, 0.15 mM EGTA, 0.07 mm okadaic acid, $11.1 \mathrm{~mm}$ sodium fluoride, $11.1 \mathrm{~mm}$ $\mathrm{MgCl}_{2}, 1 \mu \mathrm{Ci}$ of $\left[\gamma_{-}{ }^{32} \mathrm{P}\right] \mathrm{ATP}(2 \mathrm{mCi} / \mathrm{ml}$; PerkinElmer Life and Analytical Sciences), 2 mм ATP, and EDTA-free protease inhibitor cocktail (Roche Applied Science). The Cdk5 inhibitor olomoucine (Biomol Research Laboratories) was added at a concentration of $400 \mu \mathrm{m}$. The kinase reaction mix was incubated at $30^{\circ} \mathrm{C}$ for $4 \mathrm{~h}$, separated on $15 \%$ SDS-PAGE gels, and visualized by overnight exposure for autoradiography or by
Western blotting with the monoclonal 3F4 antibody or the anti-pPrP ${ }^{543}$ antiserum. Immunoreactivity was detected with HRP-conjugated antimouse or anti-rabbit secondary antibodies and ImmobilonWestern chemiluminescent HRP substrate reagents (Millipore).

PK treatment of phosphorylated PrP. Various concentrations of PK (BioShop) in $50 \mathrm{~mm}$ Tris- $\mathrm{HCl}, \mathrm{pH} 7.5$, ranging from 0 to $50 \mu \mathrm{g} / \mathrm{ml}$ were mixed with $2.3 \mu \mathrm{g}$ of $\left[\gamma_{-}{ }^{32} \mathrm{P}\right]$ phosphorylated or nonphosphorylated $\operatorname{PrP}$ in kinase reaction buffer containing freshly added $0.1 \mathrm{~mm}$ okadaic acid. The reaction mix was incubated at $4^{\circ} \mathrm{C}$ for $1 \mathrm{~h}$ or at $37^{\circ} \mathrm{C}$ for $1-4 \mathrm{~h}$. The PK-treated PrP was analyzed by autoradiography and Western blot analyses as described above.

Effect of pPrP on nonphosphorylated PrP aggregation. Two microliters $(0.9 \mu \mathrm{g}$ of total $\operatorname{PrP})$ of $\mathrm{Cdk} 5$-pPrP kinase assay or kinase assay without Cdk5 were added to $5.85 \mu \mathrm{g}$ of $\mathrm{PrP}$ in a volume of $15 \mu \mathrm{l}$ and incubated at $37^{\circ} \mathrm{C}$ for $0,24,48$, and $96 \mathrm{~h}$. After $96 \mathrm{~h}, 2 \mu \mathrm{l}$ corresponding to $0.12 \mu \mathrm{g}$ or $0.012 \mu \mathrm{g}$ of the original kinase assays were added to $5.85 \mu \mathrm{g}$ of fresh $\operatorname{PrP}$ and incubated for $24 \mathrm{~h}$ at $37^{\circ} \mathrm{C}$ (cycle 1 ) for serial propagation assays. The reaction was repeated for six cycles, transferring $2 \mu \mathrm{l}$ to fresh nonphosphorylated PrP at the end of each cycle. At the end of each cycle, $2 \mu \mathrm{l}$ aliquots were also removed and added to $10 \mu \mathrm{l}$ containing a final concentration of $0(-\mathrm{PK})$ or $10 \mu \mathrm{g} / \mathrm{ml} \mathrm{PK}(+\mathrm{PK})$ and digested at $37^{\circ} \mathrm{C}$ for $1 \mathrm{~h}$ before submitting to a $3 \mathrm{~F} 4$ Western blot.

Transmission electron microscopy. Kinase reactions were dialyzed against $5 \mathrm{~mm}$ Tris-HCl, pH 7.4, using the Slide-A-Lyzer Mini Dialysis unit (Pierce). Approximately $0.5 \mu \mathrm{l}$ of the dialyzed kinase reaction mix was deposited onto Formvar (Camemco Supplies)-coated copper grids for $2 \mathrm{~min}$, adsorbed with Whatman $1 \mathrm{M}$ filter paper, dried for $2 \mathrm{~min}$, and stained with $4 \%$ uranyl acetate. Analyses of the samples were done with an FFI TECHNAI $12120 \mathrm{~V}$ transmission electron microscope at the Facility for Electron Microscopy at McGill University. Controls consisted of nonphosphorylated PrP lacking Cdk5 in the reaction mix and Cdk5 in the absence of $\operatorname{PrP}$ in the kinase reaction mix. Aging was done by incubating phosphorylated or nonphosphorylated dialyzed $\operatorname{PrP}$ at $37^{\circ} \mathrm{C}$ for $16 \mathrm{~d}$. Samples were frozen at $-80^{\circ} \mathrm{C}$ until analysis by transmission electron microscopy.

Immunoelectron microscopy. Dialyzed $\mathrm{PrP}$ or $\mathrm{pPrP}$ were placed on the grids as described above and blocked with a solution of $2 \%$ bovine serum albumin, $2 \%$ casein, and $0.5 \%$ ovalbumin (BCO) for $5 \mathrm{~min}$. Anti-PrP antibodies were applied for $1 \mathrm{~h}$ at room temperature at a dilution of 1:10 in BCO for 3F4 and anti-pPrP ${ }^{\mathrm{S} 43}$ and 1:20 for $6 \mathrm{H} 4$. After washes in Dulbecco's PBS (DPBS) and another 5 min blocking step in BCO, samples were incubated for 30 min with 1:20 anti-rabbit or anti-mouse IgG antibodies conjugated with $10 \mathrm{~nm}$ gold particles (Sigma). After washing with DPBS, samples were stained with $4 \%$ uranyl acetate for $30 \mathrm{~s}$ to $1 \mathrm{~min}$. Controls included samples with no primary antibodies and immunostaining of amyloid $\beta$ peptide $\mathrm{A} \beta_{1-42}$ fibrils generated as described previously (Zhang et al., 2002). Coimmunostaining of PrP with $6 \mathrm{H} 4$ antibody and anti-pPrP ${ }^{\mathrm{S43}}$ antiserum was detected with anti-mouse IgG conjugated to $5 \mathrm{~nm}$ gold (Sigma) and goat anti-Affinitypure donkey anti-rabbit (heavy and light chains) conjugated to $18 \mathrm{~nm}$ gold particles (Jackson ImmunoResearch). 

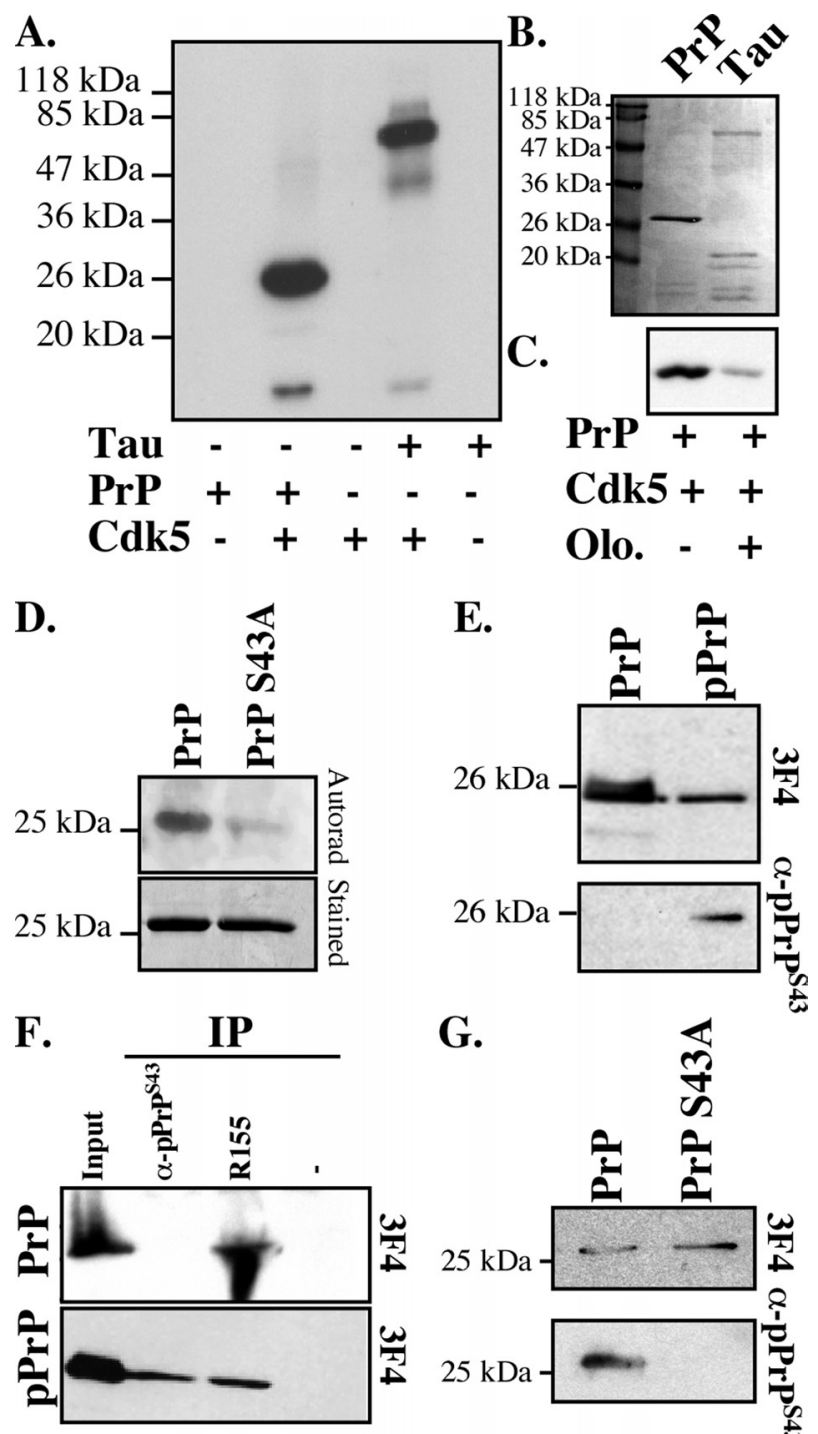

G.

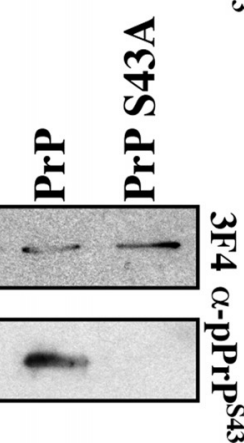

Figure 1. Cdk5 phosphorylation of human $\operatorname{PrP}_{23-231}$ at $\mathrm{S} 43$. A, Autoradiogram of Cdk5 in vitro kinase assay on $\mathrm{PrP}_{23-231}$ or Tau protein. $\boldsymbol{B}$, Coomassie blue stain of PrP and Tau protein. $\boldsymbol{C}$, Autoradiogram of in vitro Cdk5 kinase assay on PrP in the absence or presence of olomoucine (010.). D, Autoradiogram and Coomassie blue stain of in vitro C $\mathrm{dk} 5$ kinase assay on PrP and PrP S43A. E, Western blot with anti-pPrP ${ }^{543}$ antiserum and anti-PrP ${ }^{109-112} 3$ F4 antibody of $100 \mathrm{ng}$ of nonphosphorylated PrP or $100 \mathrm{ng}$ of (dk5 prP.F, Western blot with $3 \mathrm{~F} 4$ antibody of PrP and pPrP immunoprecipitated (IP) with anti-pPrP ${ }^{543}$ or anti-PrP ${ }^{36-56}$ R155 antisera. G, Western blot with 3F4 and anti-pPrP ${ }^{543}$ of Cdk5 kinase assay on PrP or PrP S43A.

Congo Red staining. Three microliters of $10 \mu \mathrm{M}$ dialyzed PrP, Cdk5phosphorylated PrP (pPrP) PK-digested Cdk5-phosphorylated PrP, fibrillar $\mathrm{A} \beta_{1-42}$ and $\mathrm{A} \beta_{42-1}$ (Zhang et al., 2002), and $0.05 \mu \mathrm{l}$ of bovine brain purified Cdk5 were applied on glass slides and dried overnight at $4^{\circ} \mathrm{C}$. Dried samples were stained for $2 \mathrm{~h}$ with Congo Red solution $(4 \mathrm{~mm}$ Congo Red, $50 \mathrm{~mm} \mathrm{NaCl}$, and $80 \% \mathrm{EtOH}$ ) filtered on a $0.5 \mu \mathrm{m}$ membrane. Samples were washed four times with $90 \%$ ethanol and dried, and pictures were taken under polarized light microscopy.

Purification of phospho-proteins. Mouse N2a cells (American Type Culture Collection) were cultured in MEM containing $10 \%$ fetal bovine serum (HyClone) and transfected with pCep $4 \beta-\mathrm{PrP}, \mathrm{pCep} 4 \beta-\mathrm{PrP} /$ pcDNA3.1-Cdk5/pcDNA3.1-p25, or pCep4 $\beta$-PrP S43A/pcDNA3.1Cdk5/pcDNA3.1-p25 (Bounhar et al., 2001; Li et al., 2007) using Lipofectamine ${ }^{2000}$ reagent (Invitrogen). Cells were maintained in culture in the presence of $100 \mathrm{~nm}$ okadaic acid (BioShop). For the roscovitine treatments, $10 \mu \mathrm{M}$ roscovitine (Biomol Research Laboratories) was added $24 \mathrm{~h}$ after the transfection, and cells were maintained in culture for an
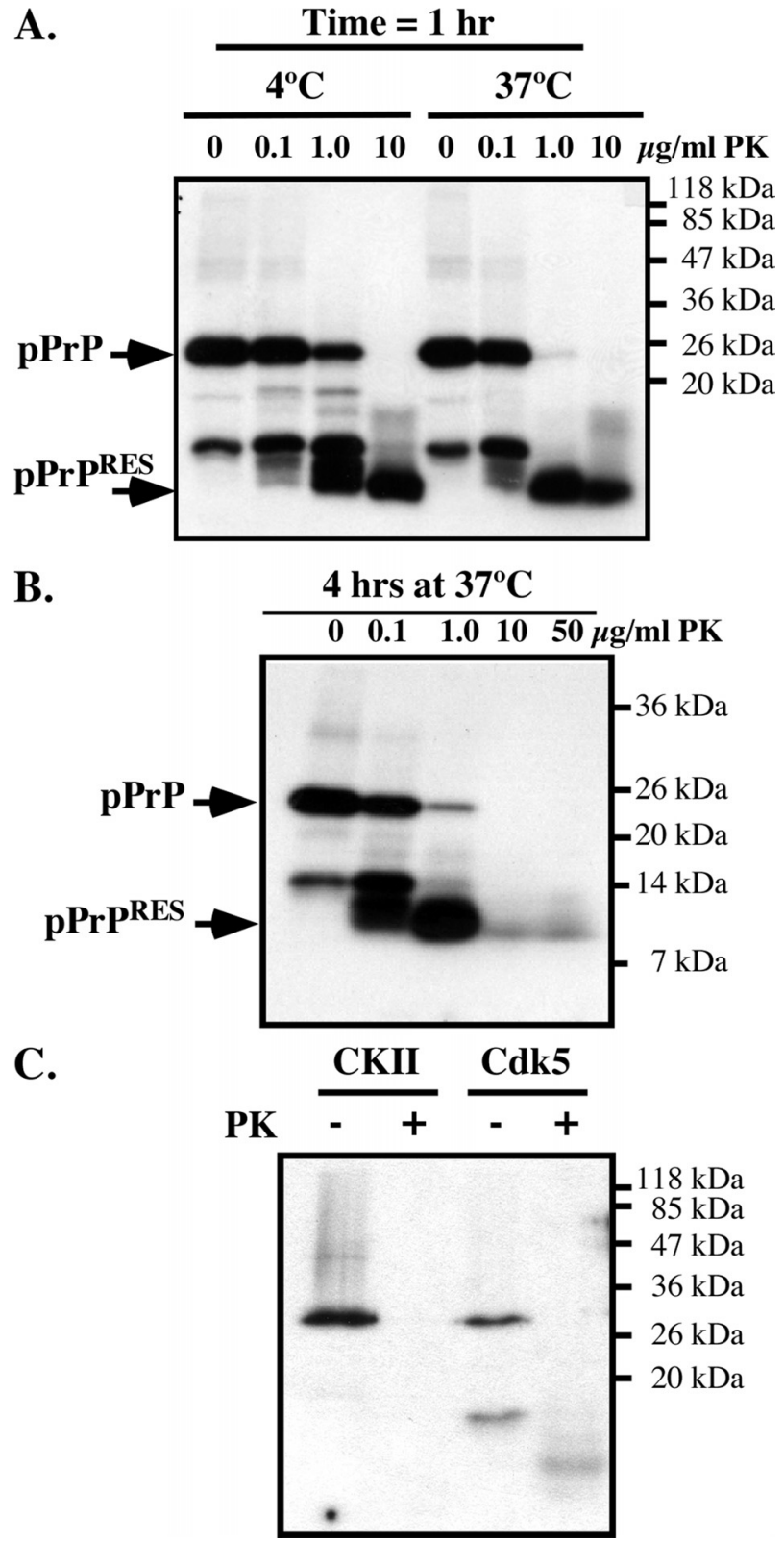

Figure 2. Cdk5-phosphorylated, but not CKII-phosphorylated, PrP is resistant to PK. A, Autoradiogram of Cdk5-phosphorylated PrP incubated with $0-10 \mu \mathrm{g} / \mathrm{ml} \mathrm{PK} \mathrm{for} 1 \mathrm{~h}$ at $4^{\circ} \mathrm{C}$ or $37^{\circ} \mathrm{C}$. $B$, Autoradiogram of Cdk5-phosphorylated PrP incubated with $0-50 \mu \mathrm{g} / \mathrm{ml} \mathrm{PK} \mathrm{for} 4 \mathrm{~h}$ at $37^{\circ} \mathrm{C}$. C, Autoradiogram of Cdk5- or CKII-phosphorylated PrP incubated with 0 or $10 \mu \mathrm{g} / \mathrm{ml} \mathrm{PK} \mathrm{for} 1 \mathrm{~h}$ at $37^{\circ} \mathrm{C}$.

additional $24 \mathrm{~h}$. Proteins were collected $48 \mathrm{~h}$ after the transfection and phospho-proteins purified with the PhosphoPurification kit according to the instructions of the manufacturer (Qiagen).

Immunohistochemistry on mice brains. C57BL/6 mice were intracerebrally inoculated with $20 \mu \mathrm{l}$ of a $1 \%$ brain homogenate from mice infected with the 22A strain of scrapie (TSE Resource Centre). The animals were killed at onset of clinical symptoms, and the whole brains were fixed in $10 \%$ Formalin and then processed and embedded in paraffin wax. Brains of age-matched, mock-infected mice were collected as controls. Four micrometer sections were deparaffinized, rehydrated, autoclaved in sodium citrate antigen retrieval buffer ( $10 \mathrm{~mm}$ sodium citrate and $0.05 \%$ Tween $20, \mathrm{pH} 6.0)$ at $121^{\circ} \mathrm{C} 30 \mathrm{~min}$, washed with TBS-T $(0.1 \%$ Triton $\mathrm{X}-100,20 \mathrm{~mm}$ Tris, and $150 \mathrm{~mm} \mathrm{NaCl}, \mathrm{pH}$ 7.5), and blocked with Power Block Universal blocking reagent (Inter Medico). The anti- $\mathrm{pPrP}^{\mathrm{S43}}$ antiserum (1:200) was incubated overnight at $4^{\circ} \mathrm{C}$, followed by washing in 
TBS-T and incubating with UltraVision One alkaline phosphatase polymer according to the UltraVision ONE Detection System protocol (Thermo Fisher Scientific). The tissue sections were counterstained with hematoxylin. When indicated, before the first antibody incubation, the sections were treated at $37^{\circ} \mathrm{C}$ for $1 \mathrm{~h}$ with $150 \mathrm{U} / \mathrm{ml}$ alkaline phosphatase (Fermentas) or 15 min with a 1:50 dilution of ready-to-use proteinase K (Dako). For the adsorption of the anti-pPrP ${ }^{S 43}$ antiserum, diluted antiserum (1: 200) was incubated overnight at $4^{\circ} \mathrm{C}$ with 20 $\mu \mathrm{g} / \mathrm{ml} \mathrm{pPrP}^{\mathrm{S43}}$ peptide, and centrifuged, and the supernatant was used as adsorbed antiserum.

\section{Results}

Cdk5 phosphorylation of $\operatorname{PrP}_{23-231}$

Several kinase motifs are highly conserved in $\operatorname{PrP}$ (Table 1). We focused on Cdk5 because it is an abundant neuronal kinase involved in neurodegeneration and neurons are the cell type most affected in prion diseases. Cdk5 phosphorylates serine-proline (SP) motifs. Prion protein has two SP phosphorylation motifs: one in the $\mathrm{N}$ terminus part of the mature protein at amino acid Ser43/Pro44 and one in the glycosyl phosphatidylinositol-anchor signal peptide at S237/P238 (Table 1). In vitro phosphorylation of $\mathrm{PrP}_{23-231}$ with $\mathrm{Cdk} 5$ showed intense phosphorylation of the full-length and a fragment of $\operatorname{PrP}_{23-231}$, similar to Cdk5 phosphorylation of the known Cdk5 substrate, Tau protein (Fig. $1 A, B)$. The Cdk5 inhibitor olomoucine essentially inhibited PrP phosphorylation (Fig. 1C). To determine whether Cdk5 phosphorylates $\mathrm{PrP}$ at S43, we mutated S43 to A43 in $\operatorname{PrP}_{23-231}$. The PrP S43A was labeled poorly compared with the wildtype protein (Fig. 1D).

We then generated an antiserum against $\mathrm{pPrP}$ at $\mathrm{S} 43$ (anti-pPrP${ }^{\mathrm{S} 43}$ ). The anti-pPrP ${ }^{\mathrm{S} 43}$ recognized the Cdk5phosphorylated PrP but not the nonphosphorylated $\mathrm{PrP}$ (Fig. 1E). Anti-pPrP $\mathrm{P}^{\mathrm{S} 3}$ immunoprecipitated Cdk5-phosphorylated PrP but not the nonphosphorylated PrP, indicating that this antiserum recognized native $\mathrm{pPrP}$ (Fig. $1 F$ ). In contrast, R155 (anti$\mathrm{PrP}^{36-56}$ ) immunoprecipitated both $\mathrm{pPrP}$ and $\operatorname{PrP}$. The anti$\mathrm{pPrP}^{\mathrm{S} 43}$ did not recognize Cdk5-phosphorylated mutant PrP S43A, thus confirming that S43 is the site of phosphorylation (Fig. 1G). Together, these results indicate that $\mathrm{S} 43$ is a major Cdk5 phosphorylation site in PrP.

\section{Cdk5-phosphorylated PrP converts to a $\mathrm{PK}^{\mathrm{RES}}$ form}

To determine whether PrP phosphorylation induces $\mathrm{PK}^{\mathrm{RES}}$, we submitted the ${ }^{32} \mathrm{P}$-phosphorylated PrP to increasing amounts of PK. A ${ }^{32} \mathrm{P}$-pPrP peptide of $\sim 10 \mathrm{kDa}$ robustly resisted a $1 \mathrm{~h}$ treatment of $10 \mu \mathrm{g} / \mathrm{ml} \mathrm{PK}$ at $4^{\circ} \mathrm{C}$ or $37^{\circ} \mathrm{C}$ (Fig. $2 A$ ) and $4 \mathrm{~h}$ of $50 \mu \mathrm{g} / \mathrm{ml}$ $\mathrm{PK}$ digestion at $37^{\circ} \mathrm{C}$ (Fig. $2 \mathrm{~B}$ ). These results indicate that the pPrP has either undergone a conformational change or developed aggregates that resist PK digestion.
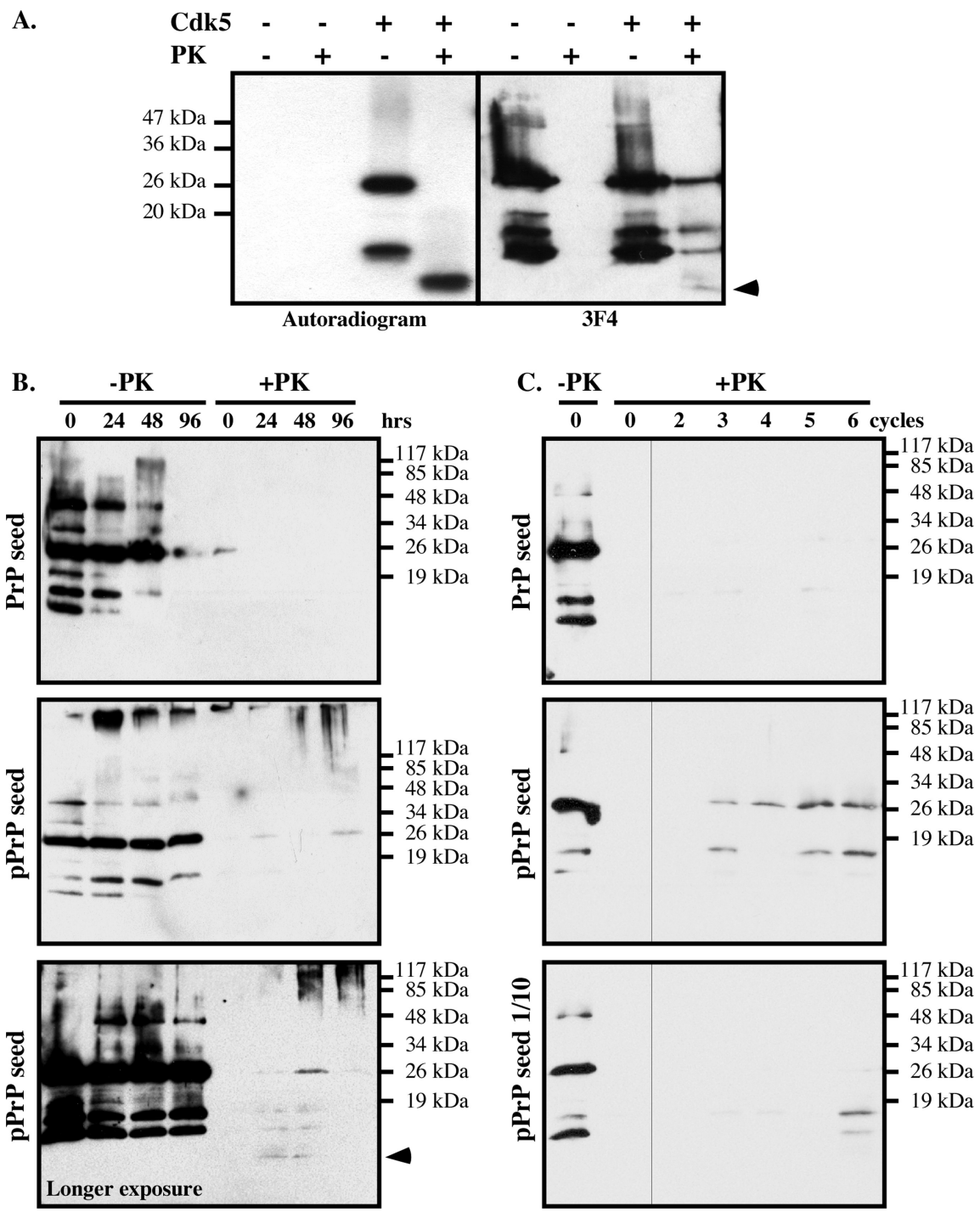

Figure 3. Cdk5-phosphorylated PrP induces the aggregation of nonphosphorylated PrP in vitro. A, Autoradiogram and Western blo indicates the $10 \mathrm{kDa}$ PrP ${ }^{\mathrm{RES}}$ fragment detected on the autoradiogram or Western blot. $\boldsymbol{B}$, PrP Western blot of nonphosphorylated PrP sed with kinase assays performed with (pPrP) or without Cdk5 and incubated for the indicated time without ( $-P K$ ) or with (+PK) PK Western blot of nonphosphorylated PrP seeded with a $2 \mu$ l aliquot of the $96 \mathrm{~h}$ time point (0 cycle) in $\boldsymbol{B}$ and incubated $24 \mathrm{~h}$ (cycle 1). Subsequent cycles represent samples in which $2 \mu$ lat the end of the incubation period was added into fresh nonphosphorylated PrP and incubated $24 \mathrm{~h}$. The bottom represents an original seed of $0.2 \mu \mathrm{l}$ of the $96 \mathrm{~h}$ time point in $\boldsymbol{B}$.

To assess whether phosphorylation at other amino acid residues can also induce $\mathrm{PK}^{\mathrm{RES}}$ of $\mathrm{PrP}, \mathrm{PrP}$ was phosphorylated with CKII, known to phosphorylate bovine PrP at Ser154 (equivalent to S143 in humans) (Negro et al., 2000). However, CKIIphosphorylated human PrP did not become $\mathrm{PK}^{\mathrm{RES}}$ (Fig. 2C). These results indicate that Cdk5-phosphorylated PrP specifically becomes $\mathrm{PK}^{\mathrm{RES}}$.

\section{Cdk5-phosphorylated PrP induces the aggregation of nonphosphorylated PrP}

To determine whether non- ${ }^{32} \mathrm{P}$-labeled $\mathrm{PrP}$ in the reaction mixture was also resistant to $\mathrm{PK}$, the $\mathrm{Cdk} 5$-phosphorylated $\mathrm{PrP}$ was immunoblotted (Fig. 3A). The nonphosphorylated PrP was completely degraded by $\mathrm{PK}$, but the Cdk5-phosphorylated PrP was not. The 3F4 antibody detected $\mathrm{PK}^{\mathrm{RES}} 25 \mathrm{kDa}$ full-length, the 16 and $18 \mathrm{kDa}$ copurified PrP fragments, and faintly the $10 \mathrm{kDa}$ 

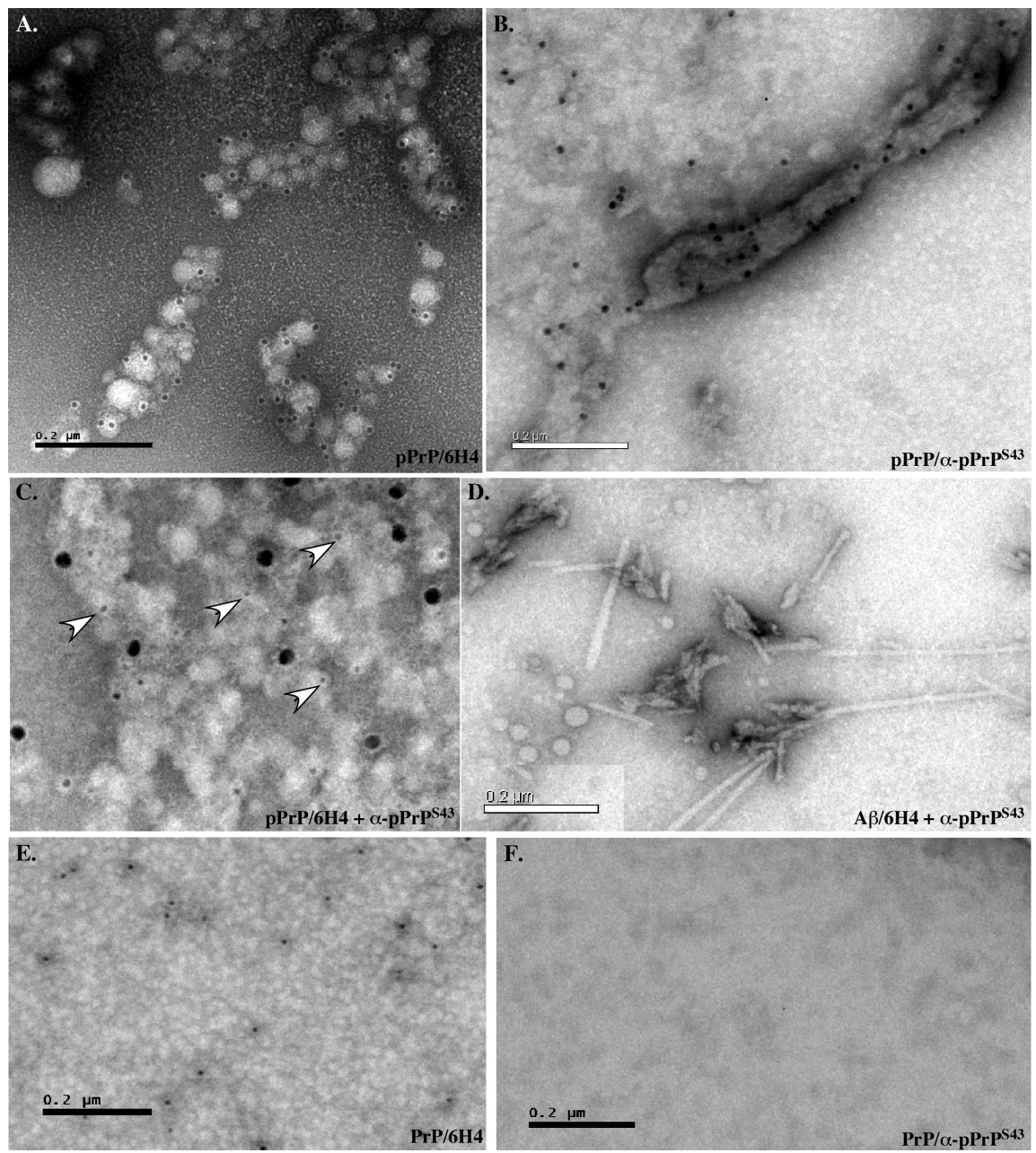

Figure 4. Cdk5-phosphorylated PrP forms aggregates. $\boldsymbol{A}-\boldsymbol{C}$, Immunostaining of pPrP with $6 \mathrm{H} 4$ (10 nm gold particle size) $(\boldsymbol{A})$, anti-pPrP ${ }^{S 43}(10 \mathrm{~nm})(\boldsymbol{B})$, or both anti-pPrP ${ }^{543}(18 \mathrm{~nm})$ and $6 \mathrm{H} 4(5 \mathrm{~nm})(\boldsymbol{C})$ antibodies. D, Control of fibrillar $A \beta_{1-42}$ immunostaining with anti-pPrP ${ }^{\$ 43}(10 \mathrm{~nm}) . \boldsymbol{E}, \boldsymbol{F}$, Immunostaining of nonphosphorylated PrP with $6 \mathrm{H} 4(10 \mathrm{~nm})(\boldsymbol{E})$ and anti-pPrP ${ }^{543}(10$ nm) $(\boldsymbol{F})$ antibodies.

radiolabeled $\operatorname{PrP}{ }^{\mathrm{RES}}$ fragment. Together, these results show that, first, the $\mathrm{PK}^{\mathrm{RES}}$ radiolabeled $10 \mathrm{kDa}$ fragment contains the phosphorylated S43, and, second, that nonphosphorylated $25 \mathrm{kDa}$ full-length PrP can become PK ${ }^{\mathrm{RES}}$ in the kinase assay. The 16 and $18 \mathrm{kDa}$ nonradiolabeled $\mathrm{PK}^{\mathrm{RES}}$ fragments either represent $\mathrm{pPrP}$ after the proteolytic cleavage of the $\mathrm{N}$ terminus of $\mathrm{PrP}$ containing the pS43 epitope or nonphosphorylated PK ${ }^{\mathrm{RES}} \mathrm{PrP}$ fragments. Seeding PrP from the Cdk5 kinase assay generated a small amount of $\mathrm{PK}^{\mathrm{RES}}$ nonphosphorylated full-length $\operatorname{PrP}$ and $\operatorname{PrP}$ fragments after $24 \mathrm{~h}$ of incubation, whereas seeding PrP from the kinase assay lacking Cdk5 did not (Fig. 3B). Furthermore, a longer exposure demonstrated an increase of the $10 \mathrm{kDa} \operatorname{PrP}$ fragment at 24 and $48 \mathrm{~h}$. At 48 and $96 \mathrm{~h}$ of incubation, aggregated PrP representing oligomers of varying sizes were also generated as evidenced by the smear at the top of the Western blot (Fig. 3B).

To assess whether pPrP can convert nonphosphorylated $\operatorname{PrP}$ into a $\mathrm{PK} \mathrm{RES}^{\mathrm{RES}}$ protein in a serial propagation assay, 2 or $0.2 \mu \mathrm{l}$ of the $96 \mathrm{~h}$ reaction mix in Figure $3 B$ was incubated $24 \mathrm{~h}$ with fresh nonphosphorylated PrP before testing for $\mathrm{PK}^{\mathrm{RES}}$, and this was repeated six times (cycles), each time seeding fresh nonphosphorylated $\operatorname{PrP}$ with $2 \mu \mathrm{l}$ of the incubation mix at the end of the $24 \mathrm{~h}$ incubation period. Increasing amounts of $\mathrm{PK}^{\mathrm{RES}}$ full-length $\mathrm{PrP}$ and PrP fragments were obtained from the Cdk5-containing ki-
$\operatorname{pPrP} / \alpha-p P r P S 4$

nase assay seeded PrP mix after three cycles but not from the non-Cdk5containing kinase assay (Fig. 3C). However, no additional amplification of the $10 \mathrm{kDa} \mathrm{PK}^{\mathrm{RES}}$ PrP fragment was obtained. Seeding with $0.2 \mu \mathrm{l}$ of the Cdk5 kinase assay also resulted in $\mathrm{PK}^{\mathrm{RES}} \mathrm{PrP}$ after six cycles. These results indicate that pPrP enhances nonphosphorylated PrP aggregation but not conversion.

\section{Cdk5-phosphorylated PrP forms aggregates and fibrils}

To evaluate the structural state of PrP after phosphorylation, we analyzed $\operatorname{PrP}$ and pPrP by transmission electron microscopy. Globular aggregates were detected in the pPrP and much less abundantly in the nonphosphorylated PrP reaction mixture (Fig. 4). The Cdk5 alone did not contain these structures (data not shown). The globular structures had various appearances: some were monomeric, whereas others were aggregated. Immunodecoration with the anti-PrP $6 \mathrm{H} 4$ and $3 \mathrm{~F} 4$ antibodies (3F4 not shown) and anti-pPrP $\mathrm{P}^{\mathrm{S} 3}$ antiserum confirmed that $\mathrm{PrP}$ and $\mathrm{pPrP}$ were present in these globular structures (Fig. $4 A, B$ ). Both epitopes colocalized but did not overlap in these globular aggregates (Fig. 4C). No immunoreactivity was observed in the absence of primary antibodies (data not shown). These two antibodies did not recognize $\mathrm{A} \beta_{1-42}$ fibrils, thus indicating specificity (Fig. $4 D$ ). The 6H4 antibody recognized nonphosphorylated $\operatorname{PrP}$ (Fig. $4 E$ ), but anti-pPrP ${ }^{\mathrm{S} 43} \mathrm{did}$ not (Fig. $4 F$ )

In addition, large fibrils were detected in transmission electron micrographs of pPrP (Fig. 5A). These increased in abundance and diversity with an incubation of the Cdk5-phosphorylated $\operatorname{PrP}$ at $37^{\circ} \mathrm{C}$ for $16 \mathrm{~d}$ (Fig. 5B), a method commonly used to enhance fibrillization of peptides. The globular aggregates also seem to become more compacted with time (Fig. 5C). In contrast, nonphosphorylated PrP remained amorphous with time of incubation (Fig. 5D).

To determine whether $\mathrm{pPrP}$ had taken an amyloid conformation, we conducted Congo Red staining (Fig. 5E). Whereas neither the PrP nor the Cdk5 preparation stained with Congo Red, Cdk5-pPrP displayed fibril-like structures with the expected apple green birefringence appearance under polarized light. These structures resembled those observed with $\mathrm{A} \beta_{1-42}$. The reverse control peptide $A \beta_{42-1}$ was negative, as expected. Treatment of the proteins with PK did not remove these Congo Red-positive structures in Cdk5-phosphorylated PrP. Together, these results show that phosphorylation of PrP induces a conformational change in PrP.

\section{Phosphorylated PrP is detected in PrP/Cdk5/p25 cotransfected $\mathrm{N} 2$ a cells}

To examine whether PrP can be phosphorylated in live cells, we transfected mouse neuroblastoma N2a cells with wild-type human PrP, Cdk5, and p25 cDNAs and isolated phospho-proteins 
from total cellular protein extracts. PrP was expressed at high levels, and most was recuperated in the flow-through of the phospho-column (Fig. 6A). Four 3F4positive $25-30 \mathrm{kDa}$ proteins were recovered in fractions $2-4$, with most of the protein eluting in fraction 3 (F3). Immunoblotting with an anti-pTyr antiserum confirmed that $\mathrm{F} 3$ contained most of the phospho-proteins. The anti$\mathrm{pPrP}^{\mathrm{S} 43}$ antiserum recognized one of the four 3F4-positive proteins in F3. To determine whether Cdk5 phosphorylated any of these pPrP, we treated the transfected cells with the Cdk5 inhibitor roscovitine. Three 3F4-positive PrP proteins were observed in the phospho fraction (Fig. 6B). Furthermore, transfection of N2a cells with full-length $\operatorname{PrP}$ S43A rather than wild-type $\operatorname{PrP}$ or wild-type $\operatorname{PrP}$ in the absence of Cdk5/p25 also yielded only three proteins (Fig. 6C,D). As expected, no 3F4 immunoreactivity was detected in the phospho-proteins purified from untransfected N2a cells (Fig. 6E). These results indicate that $\mathrm{PrP}$ is phosphorylated at $\mathrm{S} 43$ by a roscovitine-sensitive kinase. In addition, the results show additional Cdk5independent PrP phosphorylation.

\section{Alkaline phosphatase-sensitive and proteinase $\mathrm{K}$-resistant $\mathrm{pPrP}^{\mathrm{S43}}$ immunoreactivity in scrapie-infected mice brains}

To assess whether $\mathrm{pPrP}^{\mathrm{S} 43}$ could be part of the pathogenic process in scrapie infections, we immunostained coronal sections of mock-infected or 22A scrapie-infected mouse brains with the anti-pPrP ${ }^{\mathrm{S} 43}$ antiserum (Fig. 7). No immunoreactivity was detected in the mock-infected brains. However, widespread immunostaining was detected in the 22A-infected brains, especially in the medulla and thalamus region, which are the regions normally affected by the $22 \mathrm{~A}$ strain. In contrast, no immunoreactivity was detected in the hypothalamus, which shows relatively little prion-associated pathology in this model. The $\mathrm{pPrP}^{\mathrm{S} 43}$ immunoreactivity was mostly located in diffuse deposits of $\mathrm{PrP}^{\mathrm{Sc}}$ and in the cytoplasm of neurons (Fig. 8). Occasionally strong staining was also detected in the nucleus of some cells (Fig. 8). The anti-pPrP ${ }^{\$ 43}$ immunoreactivity was eliminated with a pretreatment of the tissue sections with alkaline phosphatase, thus confirming detection of the phospho-epitope by the antiserum (Fig. 7). In contrast, the immunoreactivity to $\mathrm{pPrP}^{\mathrm{S} 43}$ was preserved in $\mathrm{PK}$-treated tissue sections, indicating that $\mathrm{pPrP}$ is part of the pathogenic PrP. Immunoreactivity was completely absorbed with $\mathrm{pPrP}^{\mathrm{S} 43}$ peptide and was not detected in the absence of primary antiserum. These results indicate that $\mathrm{PK} \mathrm{KES}^{\mathrm{RE}}$ $\mathrm{pPrP}^{\mathrm{S} 43}$ is also present in infectious $\operatorname{PrP}$ diseases.

\section{Discussion}

Here, we show that neuronal Cdk5 phosphorylates PrP at amino acid residue $\mathrm{S} 43$ and that this phosphorylation results in the con-
C.

D.
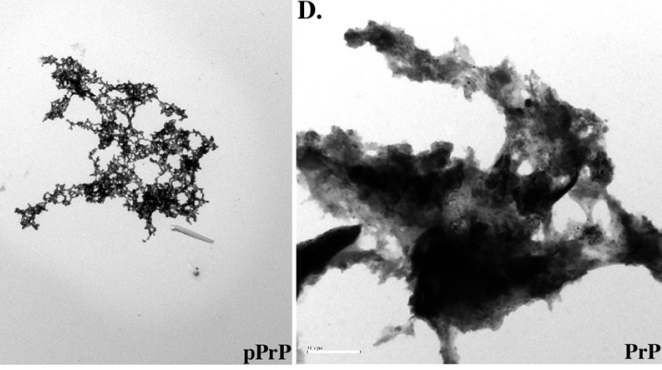

pPrP

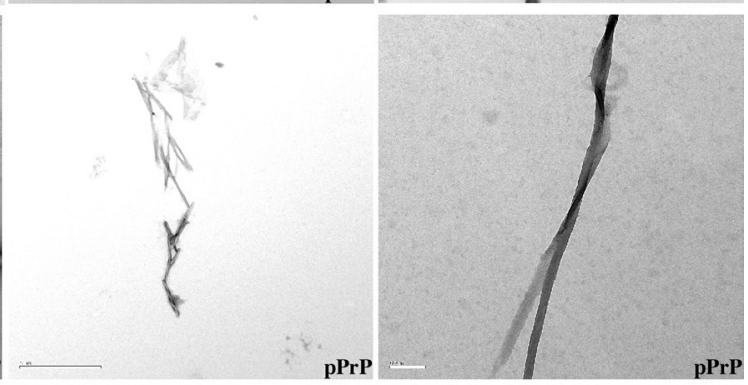

pPrP

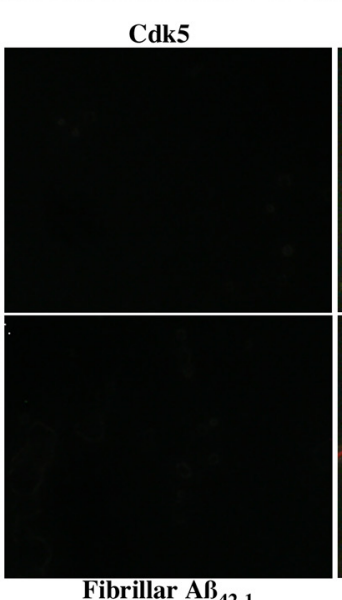
pPrP

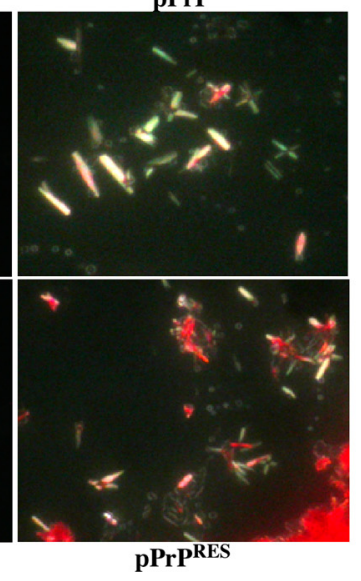

Figure 5. Cdk5-phosphorylated PrP forms fibrils. $A$, Electron micrograph of dialyzed Cdk5-phosphorylated PrP showing frillar-like structures. Scale bar, $0.5 \mu \mathrm{m} . \boldsymbol{B}$, Fibrils detected in pPrP after a $16 \mathrm{~d}$ incubation at $37^{\circ} \mathrm{C}$. Scale bar, $0.2 \mu \mathrm{m}$ for left and of nonphosphorylated PrP after a $16 \mathrm{~d}$ incubation at $37^{\circ} \mathrm{C}$. Scale bar, $0.5 \mu \mathrm{m}$. E, Congo Red staining of dialyzed PrP, Cdk5 alone, Cdk5-pPrP, PrP RES , fibrillar $A \beta_{1-42}$, and $A \beta_{42-1}$. Pictures were taken under polarized light microscopy.

version of PrP. That phosphorylated PrP is converted into a conformationally different form is evidenced by (1) $\mathrm{PK}^{\mathrm{RES}}$ of a 10 $\mathrm{kDa}$ phosphorylated PrP fragment, (2) the transformation of the phosphorylated PrP into amyloid structures that project an apple green birefringence under polarized light, and (3) the formation in time of fibrils detected by transmission electron microscopy. The conversion of PrP seems specific to Cdk5 phosphorylation at S43 because phosphorylation by CKII at S143 does not generate phosphorylated $\mathrm{PK}^{\mathrm{RES}}$ fragments of PrP.

The converted pPrP does not appear to have the ability to convert nonphosphorylated PrP into a $10 \mathrm{kDa} \mathrm{PK}^{\mathrm{RES}} \mathrm{PrP}$ fragment in vitro. Although a small amount of $\mathrm{PK}^{\mathrm{RES}} 10 \mathrm{kDa} \operatorname{PrP}$ fragment is detected after 24 and $48 \mathrm{~h}$ of incubation of nonphosphorylated PrP seeded with sixfold less of the pPrP mix, it does not further amplify in time. Furthermore, consecutive cycles of dilutions and incubations did not amplify the $10 \mathrm{kDa}$ fragment. However, as discussed below, the pPrP has the ability to enhance nonphosphorylated PrP aggregation. The lack of amplification of converted $\operatorname{PrP}$ in these experiments is consistent with the inability to convert bacterially purified $\mathrm{PrP}$ with scrapie prions in vitro 

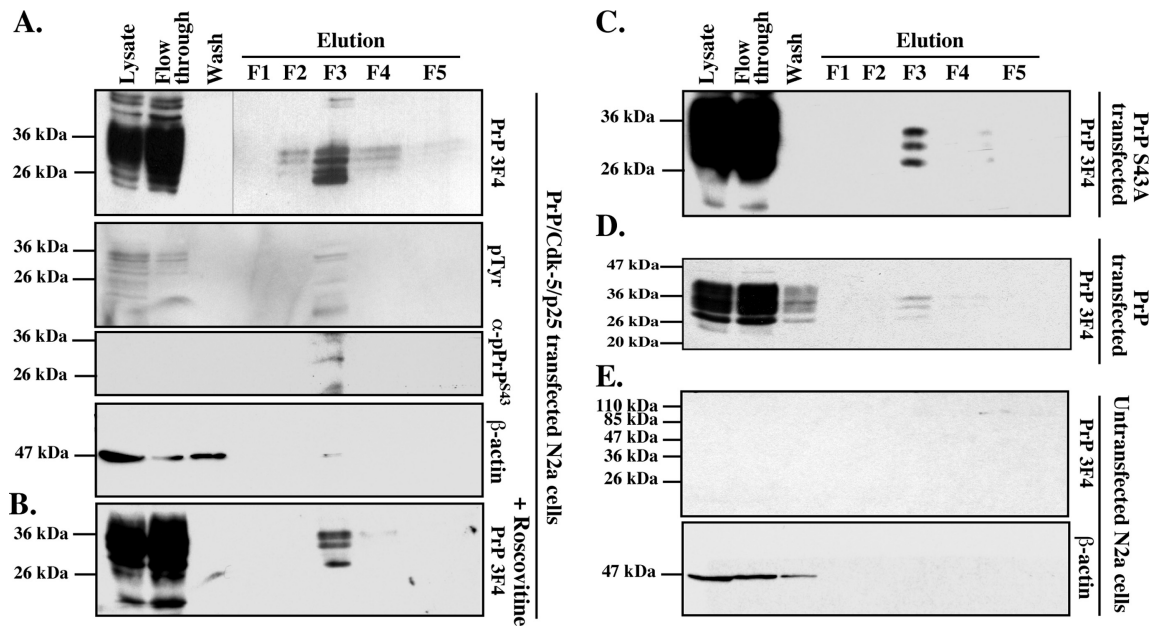

Figure 6. Purification of phosphorylated PrP from PrP/Cdk5/p25 cotransfected N2a cells protein extracts. $A-D$, Western blot analyses with 3F4, pTyr, anti-pPrP ${ }^{543}$, and $\beta$-actin on phospho-column fractionated proteins from PrP/Cdk5/p25 cotransfected N2a cells $(\boldsymbol{A})$, roscovitine-treated PrP/Cdk5/p25 cotransfected N2a cells $(\boldsymbol{B}), \operatorname{PrP}$ S43A/Cdk5/p25 cotransfected N2a cells (C), PrP-transfected N2a $(\boldsymbol{D})$, or untransfected N2a cells $(\boldsymbol{E})$.

(Deleault et al., 2005). Nevertheless, the conversion of PrP by Cdk5 phosphorylation provides a physiological molecular mechanism that could explain conversion in vivo. Alkaline phosphatase-sensitive and proteinase K-resistant $\mathrm{pPrP}^{\mathrm{S43}}$ immunoreactivity is observed in the expected strain-specific pattern of $\mathrm{PrP}^{\mathrm{Sc}}$ deposition in 22A scrapie-infected mice brains, indicating that phosphorylation of $\operatorname{PrP}$ occurs in pathological conditions. Phosphorylation is a well known mechanism of enzymatic activation through the induction of protein conformational change. Phosphorylation either changes the tertiary structure of globular proteins or has a direct effect on the dihedral backbone of the protein (Tholey et al., 1999). Because the prion protein $\mathrm{N}$ terminus is highly flexible (Donne et al., 1997; Zahn et al., 2000), it is possible that the phosphorylation at S43 provides a higherordered structure or allows electrostatic interactions with other amino acids intramolecularly or intermolecularly to generate PK resistance.

Although we could not observe an amplification of the $10 \mathrm{kDa}$ pPrP fragment in nonphosphorylated PrP, the phosphorylation of $\mathrm{PrP}$ induced $\mathrm{PK}^{\mathrm{RES}}$ of nonphosphorylated $\mathrm{PrP}$ in vitro. These $\mathrm{PK}^{\mathrm{RES}}$ forms of PrP are likely produced by aggregation because of the coexistence, but not overlap, of the $\mathrm{prrP}^{\mathrm{S} 43}$ and $6 \mathrm{H} 4$ epitopes in PrP protein aggregates detected by electron microscopy. Furthermore, $\mathrm{pPrP}$ promotes $\mathrm{PK}^{\mathrm{RES}}$ of full-length and 16 or $18 \mathrm{kDa}$ fragments of PrP. Because the size of the nonphosphorylated PrP does not shift with PK treatment, these results infer that $\mathrm{pPrP}$ induces nonphosphorylated $\mathrm{PrP}$ aggregation rather than conversion. This assumption is further supported by a time-dependent increase in high-molecular-weight PrP aggregates and full-length $\operatorname{PrP}$ when recombinant nonphosphorylated $\operatorname{PrP}$ is seeded with sixfold less pPrP reaction mix and incubated at $37^{\circ} \mathrm{C}$. Furthermore, serial propagation of $\mathrm{pPrP}$, originally diluted 50 - or 500 fold from the kinase assay, into recombinant nonphosphorylated $\mathrm{PrP}$, resulted in the production of $\mathrm{PK}^{\mathrm{RES}} \mathrm{PrP}$ after three and six cycles of incubation, respectively. Therefore, $\mathrm{pPrP}$ enhances aggregation rather than converts nonphosphorylated PrP. However, we cannot exclude the possibility that, over a very long period of time, the pPrP may actually convert nonphosphorylated PrP.

In transmissible prion diseases, $\mathrm{PrP}$ conversion is thought to occur either by template-directed conversion of $\mathrm{PrP}$ or by seeded nucleation (for review, see Aguzzi and Polymenidou, 2004). In template-directed conversion, the converted PrP molecule recruits and changes the conformation of normal PrP. In seeded nucleation, the conformationally abnormal protein recruits additional abnormal proteins to form a scaffold of abnormal proteins. However, the mechanism involved in the initial conversion of $\operatorname{PrP}$ is unknown. Phosphorylation may represent a physiological event that can originally convert PrP. The negative charges of the phosphate group may act in a manner similar to other anionic molecules, such as RNA, anionic lipid bicelles, low $\mathrm{pH}$ conditions, and synthetic poly-anions that have been shown to induce PrP conversion in vitro (Deleault et al., 2003, 2005, 2007; Supattapone, 2004; Geoghegan et al., 2007).

We cannot affirm that the $\mathrm{pPrP}^{\mathrm{S} 43}$ epitope in vivo is the result of only Cdk5 phosphorylation because other kinases, such as mitogenactivated protein kinase and GSK $3 \beta$, may also phosphorylate this residue. However, given that Cdk 5 is known as a neuronal kinase associated with several pathological events in neurodegenerative diseases, including translocation from the nuclei to the cytosol (Zhang et al., 2008), our results suggest neuronal specificity to this modification of PrP. In addition, PrP is phosphorylated at sites other than S43 and independently from Cdk5 in N2a cells. The three additional pPrP forms observed in $\mathrm{N} 2 \mathrm{a}$ cells could represent alternative phosphorylation by other kinases or phosphorylated $\operatorname{PrP}$ that is differentially glycosylated or posttranslationally modified. Others have reported in vitro phosphorylation of bovine PrP with protein kinase C, CKII, and two tyrosine kinases, Lyn and c-Fgr (Negro et al., 2000). However, the effect of phosphorylation on PrP conformation was not reported. We have shown here that CKII phosphorylation of PrP does not induce $P K^{\mathrm{RES}}$. Additional investigations into the role of phosphorylation by the various kinases in either the normal PrP function or in the pathological PrP disease mechanism are warranted by these initial findings.

Phosphorylation-dependent conversion of non-enzyme proteins may be a general mechanism associated with neurodegenerative diseases. Phosphorylation is associated with conversion of $\alpha$-synuclein and Tau protein in Parkinson disease and Alzheimer disease, respectively (Okochi et al., 2000; Fujiwara et al., 2002). Phosphorylated $\alpha$-synuclein becomes $\mathrm{PK}^{\mathrm{RES}}$ and misfolded in disease (Neumann et al., 2002), and phosphorylated Tau resists calpain- and thrombin-mediated degradation (Litersky and Johnson, 1992; Arai et al., 2005). However, there is no direct evidence that phosphorylation induces a conformational change of these proteins. Our results with recombinant prion protein show that Cdk5-dependent phosphorylation is directly responsible for the conversion of prion protein. These results raise the possibility that other cytosolic proteins undergo a phosphorylation-dependent conformational change in disease.

In summary, we showed in this study an entirely physiological condition that could explain PrP conversion in prion diseases. This work has two important implications. First, the phosphorylated PrP epitope at S43 may be an excellent candidate for diagnostic purposes. Second, if phosphorylation of $\mathrm{PrP}$ at S43 is involved in the pathophysiology of disease, inhibitors of SP- 
directed kinases could be used as a therapeutic intervention against prion diseases.

\section{References}

Aguzzi A, Polymenidou M (2004) Mammalian prion biology: one century of evolving concepts. Cell 116:313-327.

Arai T, Guo JP, McGeer PL (2005) Proteolysis of non-phosphorylated and phosphorylated tau by thrombin. J Biol Chem 280:5145-5153.

Atarashi R, Moore RA, Sim VL, Hughson AG, Dorward DW, Onwubiko HA, Priola SA, Caughey B (2007) Ultrasensitive detection of scrapie prion protein using seeded conversion of recombinant prion protein. Nat Methods 4:645-650.

Bessen RA, Kocisko DA, Raymond GJ, Nandan S, Lansbury PT, Caughey B (1995) Non-genetic propagation of strain-specific properties of scrapie prion protein. Nature 375:698-700.

Bocharova OV, Makarava N, Breydo L, Anderson M, Salnikov VV, Baskakov IV (2006) Annealing prion protein amyloid fibrils at high temperature results in extension of a proteinase K-resistant core. J Biol Chem 281:2373-2379.

Bounhar Y, Zhang Y, Goodyer CG, LeBlanc A (2001) Prion protein protects human neurons against Bax-mediated apoptosis. J Biol Chem 276:39145-39149.

Breydo L, Bocharova OV, Makarava N, Salnikov VV, Anderson M, Baskakov IV (2005) Methionine oxidation interferes with conversion of the prion protein into the fibrillar proteinase K-resistant conformation. Biochemistry 44:15534-15543.

Caughey B (1993) Scrapie associated PrP accumulation and its prevention: insights from cell culture. Br Med Bull 49:860-872.

Chiesa R, Piccardo P, Ghetti B, Harris DA (1998) Neurological illness in transgenic mice expressing a prion protein with an insertional mutation. Neuron 21:1339-1351.

Deleault NR, Lucassen RW, Supattapone S (2003) RNA molecules stimulate prion protein conversion. Nature 425:717-720.

Deleault NR, Geoghegan JC, Nishina K, Kascsak R, Williamson RA, Supattapone S (2005) Protease-resistant prion protein amplification reconstituted with partially purified substrates and synthetic polyanions. J Biol Chem 280:26873-26879.

Deleault NR, Harris BT, Rees JR, Supattapone S (2007) Formation of native prions from minimal components in vitro. Proc Natl Acad Sci U S A 104:9741-9746.

Donne DG, Viles JH, Groth D, Mehlhorn I, James TL, Cohen FE, Prusiner SB, Wright PE, Dyson HJ (1997) Structure of the recombinant fulllength hamster prion protein $\operatorname{PrP}(29-231)$ : the $\mathrm{N}$ terminus is highly flexible. Proc Natl Acad Sci U S A 94:13452-13457.

Fujiwara H, Hasegawa M, Dohmae N, Kawashima A, Masliah E, Goldberg MS, Shen J, Takio K, Iwatsubo T (2002) alpha-Synuclein is phosphorylated in synucleinopathy lesions. Nat Cell Biol 4:160-164.

Geoghegan JC, Valdes PA, Orem NR, Deleault NR, Williamson RA, Harris BT, Supattapone S (2007) Selective incorporation of polyanionic molecules into hamster prions. J Biol Chem 282:36341-36353.

Gilch S, Wopfner F, Renner-Müller I, Kremmer E, Bauer C, Wolf E, Brem G,
PBS-injected
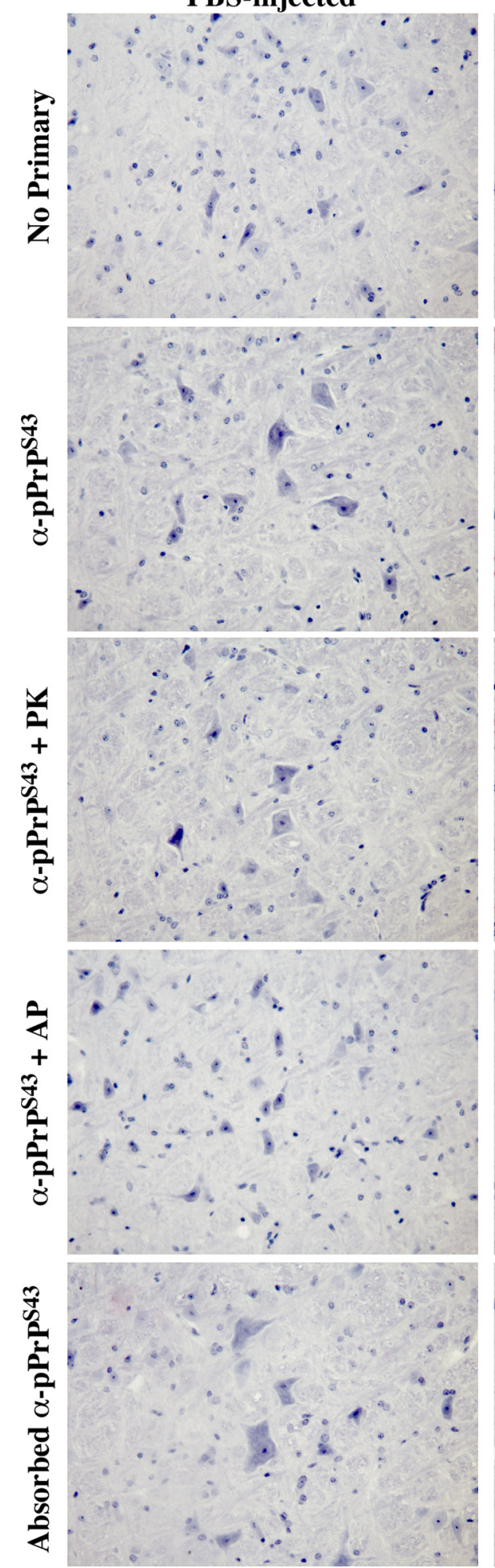

22A-infected
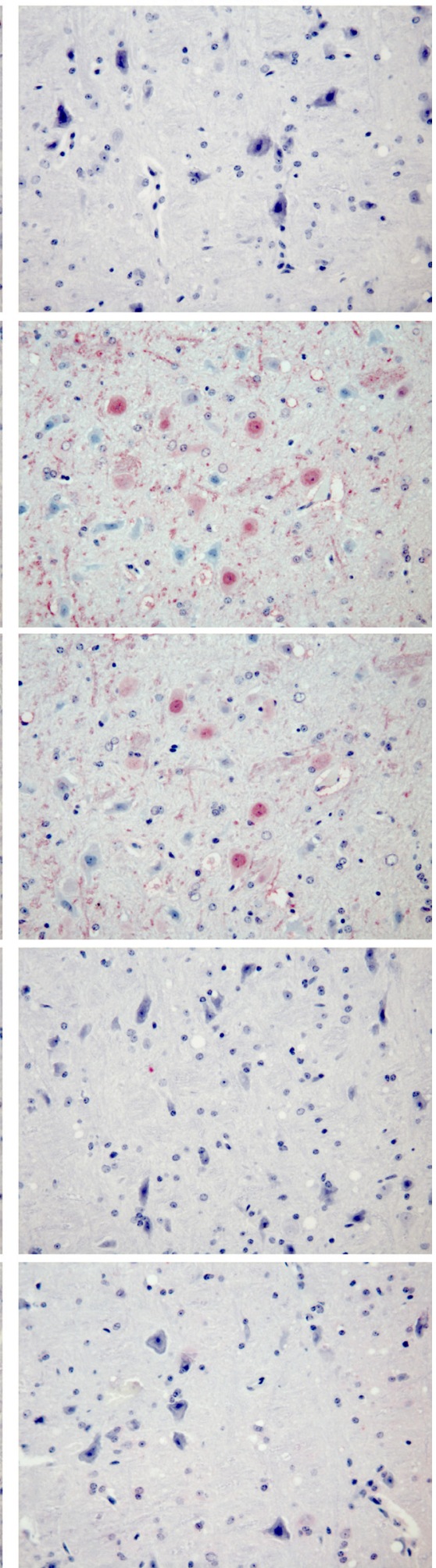

Figure 7. Immunohistological staining of control PBS- and 22A scrapie-infected mice brains. Micrographs of control PBSinjected or 22A-infected mice brain tissue sections of the medulla untreated (no primary, anti-pPrP ${ }^{\$ 43}$, adsorbed anti-pPrP ${ }^{543}$ ), pretreated with PK (anti-pPrP ${ }^{\$ 43}+$ PK), or pretreated with alkaline phosphatase (anti-pPrP $\left.{ }^{\$ 43}+A P\right)$ with anti-pPrP ${ }^{543}$, no primary antiserum, or adsorbed anti-pPrP ${ }^{543}$.

Groschup MH, Schätzl HM (2003) Polyclonal anti-PrP auto-antibodies induced with dimeric PrP interfere efficiently with PrPSc propagation in prion-infected cells. J Biol Chem 278:18524-18531.

Grasbon-Frodl E, Lorenz H, Mann U, Nitsch RM, Windl O, Kretzschmar HA 


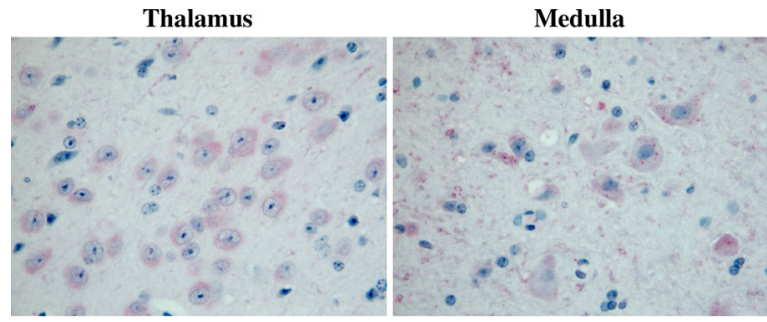

Cytosolic pPrPS43

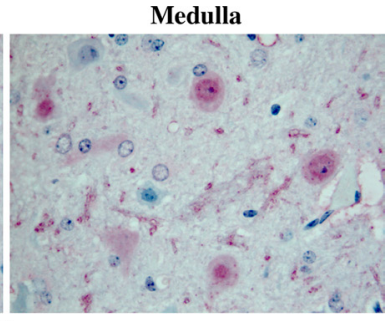

Nuclear pPrPS43

Figure 8. Cytosolic and nuclear $\mathrm{PPr}^{543}$ staining of $22 \mathrm{~A}$ scrapie-infected mice brains. Higher magnification of micrographs of $22 \mathrm{~A}$-infected mice brain tissue sections from the thalamus or the medulla immunostained with anti-PrP ${ }^{543}$.

Okochi M, Walter J, Koyama A, Nakajo S, Baba M, Iwatsubo T, Meijer L, Kahle PJ, Haass C (2000) Constitutive phosphorylation of the Parkinson's disease associated alphasynuclein. J Biol Chem 275:390-397.

Paudel HK, Lew J, Ali Z, Wang JH (1993) Brain proline-directed protein kinase phosphorylates tau on sites that are abnormally phosphorylated in tau associated with Alzheimer's paired helical filaments. J Biol Chem 268:23512-23518.

Piccardo P, Liepnieks JJ, William A, Dlouhy SR, Farlow MR, Young K, Nochlin D, Bird TD, Nixon RR, Ball MJ, DeCarli C, Bugiani O, Tagliavini F, Benson MD, Ghetti B (2001) Prion proteins with different conformations accu-

(2004) Loss of glycosylation associated with the T183A mutation in human prion disease. Acta Neuropathol 108:476-484.

Hsiao KK, Scott M, Foster D, Groth DF, DeArmond SJ, Prusiner SB (1990) Spontaneous neurodegeneration in transgenic mice with mutant prion protein. Science 250:1587-1590.

Jackson GS, Hosszu LL, Power A, Hill AF, Kenney J, Saibil H, Craven CJ, Waltho JP, Clarke AR, Collinge J (1999) Reversible conversion of monomeric human prion protein between native and fibrilogenic conformations. Science 283:1935-1937.

Jodoin J, Laroche-Pierre S, Goodyer CG, LeBlanc AC (2007) Defective retrotranslocation causes loss of anti-Bax function in human familial prion protein mutants. J Neurosci 27:5081-5091.

Kascsak RJ, Rubenstein R, Merz PA, Tonna-DeMasi M, Fersko R, Carp RI, Wisniewski HM, Diringer H (1987) Mouse polyclonal and monoclonal antibody to scrapie-associated fibril proteins. J Virol 61:3688-3693.

Kocisko DA, Come JH, Priola SA, Chesebro B, Raymond GJ, Lansbury PT, Caughey B (1994) Cell-free formation of protease-resistant prion protein. Nature 370:471-474.

Legname G, Baskakov IV, Nguyen HO, Riesner D, Cohen FE, DeArmond SJ, Prusiner SB (2004) Synthetic mammalian prions. Science 305:673-676.

Li T, Chalifour LE, Paudel HK (2007) Phosphorylation of protein phosphatase 1 by cyclin-dependent protein kinase 5 during nerve growth factorinduced PC12 cell differentiation. J Biol Chem 282:6619-6628.

Litersky JM, Johnson GV (1992) Phosphorylation by cAMP-dependent protein kinase inhibits the degradation of tau by calpain. J Biol Chem 267:1563-1568.

Lührs T, Zahn R, Wüthrich K (2006) Amyloid formation by recombinant full-length prion proteins in phospholipid bicelle solutions. J Mol Biol 357:833-841.

Ma J, Lindquist S (2002) Conversion of PrP to a self-perpetuating PrPSclike conformation in the cytosol. Science 298:1785-1788.

Ma J, Wollmann R, Lindquist S (2002) Neurotoxicity and neurodegeneration when PrP accumulates in the cytosol. Science 298:1781-1785.

Mastrianni JA, Capellari S, Telling GC, Han D, Bosque P, Prusiner SB, DeArmond SJ (2001) Inherited prion disease caused by the V210I mutation: transmission to transgenic mice. Neurology 57:2198-2205.

Monari L, Chen SG, Brown P, Parchi P, Petersen RB, Mikol J, Gray F, Cortelli P, Montagna P, Ghetti B, et al (1994) Fatal familial insomnia and familial Creutzfeldt-Jakob disease: different prion proteins determined by a DNA polymorphism. Proc Natl Acad Sci U S A 91:2839-2842.

Neary K, Caughey B, Ernst D, Race RE, Chesebro B (1991) Protease sensitivity and nuclease resistance of the scrapie agent propagated in vitro in neuroblastoma cells. J Virol 65:1031-1034.

Negro A, Meggio F, Bertoli A, Battistutta R, Sorgato MC, Pinna LA (2000) Susceptibility of the prion protein to enzymic phosphorylation. Biochem Biophys Res Commun 271:337-341.

Neumann M, Kahle PJ, Giasson BI, Ozmen L, Borroni E, Spooren W, Müller V, Odoy S, Fujiwara H, Hasegawa M, Iwatsubo T, Trojanowski JQ, Kretzschmar HA, Haass C (2002) Misfolded proteinase K-resistant hyperphosphorylated alpha-synuclein in aged transgenic mice with locomotor deterioration and in human alpha-synucleinopathies. J Clin Invest 110:1429-1439. mulate in Gerstmann-Straussler-Scheinker disease caused by A117V and F198S mutations. Am J Pathol 158:2201-2207.

Prusiner SB (1982) Novel proteinaceous infectious particles cause scrapie. Science 216:136-144.

Race RE, Fadness LH, Chesebro B (1987) Characterization of scrapie infection in mouse neuroblastoma cells. J Gen Virol 68:1391-1399.

Ricchelli F, Buggio R, Drago D, Salmona M, Forloni G, Negro A, Tognon G, Zatta P (2006) Aggregation/fibrillogenesis of recombinant human prion protein and Gerstmann-Straussler-Scheinker disease peptides in the presence of metal ions. Biochemistry 45:6724-6732.

Roucou X, Guo Q, Zhang Y, Goodyer CG, LeBlanc AC (2003) Cytosolic prion protein is not toxic and protects against Bax-mediated cell death in human primary neurons. J Biol Chem 278:40877-40881.

Saborio GP, Permanne B, Soto C (2001) Sensitive detection of pathological prion protein by cyclic amplification of protein misfolding. Nature 411:810-813.

Sokolowski F, Modler AJ, Masuch R, Zirwer D, Baier M, Lutsch G, Moss DA, Gast K, Naumann D (2003) Formation of critical oligomers is a key event during conformational transition of recombinant syrian hamster prion protein. J Biol Chem 278:40481-40492.

Supattapone S (2004) Prion protein conversion in vitro. J Mol Med 82:348-356.

Swietnicki W, Petersen R, Gambetti P, Surewicz WK (1997) pH-dependent stability and conformation of the recombinant human prion protein $\operatorname{PrP}(90-231)$. J Biol Chem 272:27517-27520.

Swietnicki W, Morillas M, Chen SG, Gambetti P, Surewicz WK (2000) Aggregation and fibrillization of the recombinant human prion protein huPrP90-231. Biochemistry 39:424-431.

Tateishi J, Kitamoto T (1995) Inherited prion diseases and transmission to rodents. Brain Pathol 5:53-59.

Tholey A, Lindemann A, Kinzel V, Reed J (1999) Direct effects of phosphorylation on the preferred backbone conformation of peptides: a nuclear magnetic resonance study. Biophys J 76:76-87.

Torrent J, Marchal S, Tortora P, Lange R, Balny C (2004) High pressure, an alternative approach to understand protein misfolding diseases. Cell Mol Biol (Noisy-le-grand) 50:377-385.

Wang F, Yang F, Hu Y, Wang X, Wang X, Jin C, Ma J (2007) Lipid interaction converts prion protein to a PrPSc-like proteinase K-resistant conformation under physiological conditions. Biochemistry 46:7045-7053.

Xiong LW, Raymond LD, Hayes SF, Raymond GJ, Caughey B (2001) Conformational change, aggregation and fibril formation induced by detergent treatments of cellular prion protein. J Neurochem 79:669-678.

Zahn R, Liu A, Lührs T, Riek R, von Schroetter C, López García F, Billeter M, Calzolai L, Wider G, Wüthrich K (2000) NMR solution structure of the human prion protein. Proc Natl Acad Sci U S A 97:145-150.

Zhang J, Cicero SA, Wang L, Romito-Digiacomo RR, Yang Y, Herrup K (2008) Nuclear localization of Cdk5 is a key determinant in the postmitotic state of neurons. Proc Natl Acad Sci U S A 105:8772-8777.

Zhang Y, McLaughlin R, Goodyer C, LeBlanc A (2002) Selective cytotoxicity of intracellular amyloid beta peptide1-42 through p53 and Bax in cultured primary human neurons. J Cell Biol 156:519-529. 